\title{
A CRITICAL REVIEW OF YOUTH-ORIENTED POLICIES \\ IN THE REPUBLIC OF MOLDOVA FROM THE PERSPECTIVE OF YOUTH TRANSITION REGIME
}

\author{
Mariana CRISMARU1, \\ National Institute for Economic Reseach
}

\author{
DOI: https://doi.org/10.36004/nier.es.2020.2-11 \\ JEL Classification: I31, I38 \\ UDC: $303+304](478)$
}

\begin{abstract}
Youth issues have long been a focus of policy in Moldova, despite an uneven trend over time. The aim of the article is to analyze the main policy documents devoted to youth within key policy areas that invest in the development and efficient use of human capital from the perspective of the Youth Transition Regime. A mixed-method approach was applied: situation and contextual analysis, review and analysis of policy documents, reports and studies targeting young people. The review and analysis of policy framework has revealed that although youth issues are promoted through various policies, there is a lack of an integrated approach and a comprehensive evaluation mechanism on the implementation of youth policies, including cross-sectoral dimension. Youth-related policies falls into a 'transitional regime characterized by an integrated education system, high rate of early leavers from education and training, high level of youth rate Not in Education Employment or Training - NEET, low popularity/ prominence of Vocational Education and Training, poor concordance between the education system and the labour market. The evaluation of policy measures intended to facilitate the transition of young people to adulthood shows that individualized and compensatory approaches predominate. Policy actions are focused mainly on youth skills development and less on structural policy measures in crosssectoral areas. There is a need to review and adaptyouth policies and strategies to the current and real needs of youth by promoting participatory approaches that would reflect the diversity of youth in Moldova, especially in socially vulnerable groups.
\end{abstract}

Keywords: young people, challenges, youth policy, transition regimes, welfare citizenship.

Problemele tinerilor au constituit o sursă de preocupări pentru dezvoltarea unor politici de tineret în Republica Moldova, deși a avut o evoluție oscilantă de-a lungul anilor. Scopul articolului este de a analiza principalele documente de politici destinate tinerilor în domenii-cheie care investesc în dezvoltarea și utilizarea eficientă a capitalului uman din perspectiva regimului de tranziție al tinerilor. A fost aplicată metoda mixtă: analiza situației și contextuală, cartografierea și analiza documentelor de politici, rapoarte și studii care vizează tinerii. Analiza cadrului de politici au arătat că în pofida unui număr important de strategii, programe destinate tinerilor, se atestă lipsa unei abordări integrate și a unui mecanism de evaluare complex privind implementarea politicilor de tineret. Politica de tineret se încadrează în regimul "tranzitoriu” caracterizat printr-un sistem de educație integrat, o rată ridicată a părăsirii timpurii a educației și formării, un nivel ridicat al ratei tinerilor înafara sistemului de educație, ocupare și formare profesională - NEET, o popularitate/proeminență scăzută a învățământului profesional tehnic, o concordanță slabă între sistemul de învățământ și piața muncii. Evaluarea măsurilor de politici menite să faciliteze tranziția tinerilor la viaţa de adult arată că predomină abordările individualizate și compensatorii. Măsurile de politici se concentrează mai mult pe abilitarea profesională și soluționarea deficiențelor individuale și mai puțin pe măsuri structurale în domenii intersectoriale. Este necesară revizuirea adaptarea politicilor și strategiile pentru tineret la nevoile lor actuale și reale, promovând abordări participative care să reflecte diversitatea tinerilor din Moldova, în special grupurile social vulnerabile.

Cuvinte-cheie: persoane tinere, provocări, politici de tineret, regimuri de tranziție, cetățenie social.

${ }^{1}$ ID ORCID 0000-0003-2802-5376 email: mariana.crismaru@yahoo.com

December No. 2/2020 
Проблемы молодежи на протяжение долгого времени является предметом внимания политики Молдовы, несмотря на неравномерную тенденцию. Цель статьи - проанализировать основные документы по вопросам политики связанные с молодежью в ключевых областях, которые инвестируют в развитие и эффективное использование человеческого капитала с точки зрения молодежного переходного режима. Применялся смешанный подход: ситуационный и контекстный анализ, обзор и анализ стратегических документов, отчетов и исследований, ориентированных на молодежь. Обзор и анализ стратегических документов показали, что хотя вопросы молодежи продвигаются в рамках различных политик, отсутствует комплексный подход и всеобъемлющий механизм оценки реализации молодежной политики, включая межсекторальный аспект. Политика, связанная с молодежью, относится к «переходному» режиму, характеризующемуся интегрированной системой образования, высоким показателем досрочного ухода из образования и профессиональной подготовки, высоким уровнем показателя молодежи вне сферы образования, занятости и профессиональной подготовки NEET, низкой популярностью/релевантностью профессионального образования и обучения, плохим соответствием между системой образования и рынком труда. Оценка политических мер, направленных на содействие перехода молодых людей к взрослой жизни, показывает, что преобладают индивидуализированные и компенсационные подходы. Действия политики сосредоточены в основном на развитии навыков молодежи и меньше на мерах структурной политики в межсекторальных областях. Необходимо пересмотреть и адаптировать молодежную политику и стратегии к их текущим и реальным потребностям, продвигая совместные подходы, которые отражали бы разнообразие молодежи в Молдове, особенно социально уязвимых групп.

Ключевые слова: молодежь, вызовы, молодежная политика, переходные режимы, социальное гражданство.

\section{INTRODUCTION}

It is widely agreed that investing now in human capital of youth will provide long-term benefits and contribute to the inclusive and sustainable economic growth of the country. Thus, it would possible to take advantage of the benefits of an active, innovative and skilled workforce and avoid significant social and economic costs due to educational and occupational exclusion of young people. There are also youth challenges related to demographic changes, high emigration rate, weak correlation of the education and training system with labour market requirements, poverty, social exclusion and other issues. These challenges create the requirement for a strong government's political commitment and need for specific policies and strategies tailored to certain categories of young people.

Broadly defined, national youth policy is 'a government's commitment and practice towards ensuring good living conditions and opportunities for the young population of a country' (Denstad, 2009), as well is `a long-term strategy, a general framework accompanied by an action plan to be implemented in the youth field, previously approved by a governmental structure or public authority (Pîslaru, 2019). According to country strategic documents, the youth policy in Moldova is 'a set of principles, methods and measures designed to ensure participation opportunities, well-being, personal and professional development for young people` (Law on Youth, 2016). At least declaratively, it represents an integrated cross-sectorial approach, addressed to and involving young people, while starting from their needs.

The main aim of the article is to describe and analyse main policy initiatives in Moldova devoted to youth within key policy areas that invest in the development and efficient use of human capital and are relevant for the Youth Transition Regime. This includes an institutional and policy framework related to the education and training system, employment regulation and social security and protection system with an emphasis on youth transition policies. In addition, the extent to which these policies respond to the problems and needs of young people is estimated by taking the main indicators in the targeted areas as points of reference.

Despite high-level policy advocacy, the comprehensive and integrated youth policy has remained largely rhetorical and is scarcely studied based on new approaches. This study intends to 
cover this gap by making interferences along the dimensions of youth transition theories. Moreover, the study targets to emphasize priority areas for future actions and measure by government for the development of a more comprehensive national youth policy.

\section{LITERATURE REVIEW}

Youth policy should respond to both country specific problems as well as global trends and challenges. Most studies in the field show that global trends and social changes, such as increasing inequality and exclusion, labour market insecurity, family fragility have affected the younger generations to a greater extent than the older ones (Taylor-Gooby, 2005; Walther \& Pohl, 2007). The current era is usually characterized by the notion of 'de-standardization' (Walther \& Pohl, 2007) with important implications on the process of transition of young people towards adulthood, which involves a greater variety of family models and lifestyles, diversified educational pathways, as well as longer, varied, unstable and uncertain transitions to work (Leccardi, 2006), (Ganta \& Shamchiyeva, 2016).

Similar to other countries in the region, young people in Moldova face multiple and interdependent challenges. The Youth Multidimensional Deprivation Indicator (Y-MDI) ${ }^{1}$ shows that more than one-third (36.2\%) of youth suffer from deprivation in multiple wellbeing dimensions such as education, employment, health, civic participation and social inclusion. Deprivations in employment and civic participation are more significant (40.5\% and $41.4 \%$ respectively) (OECD, 2016). Moreover, many young people in Moldova are facing poverty and social exclusion, while the places of residence in which they live and work are most likely to influence their standard of living. Thus, there is evidence of widening social inequality between young people in rural areas compared to urban areas. Rural settlements, as well as small towns, have lower economic potential, higher poverty levels, limited access to many goods and services and also fewer opportunities for the development of young human capital (Crismaru, Gagauz, \& Buciuceanu-Vrabie, 2018).

A particular concern is youth integration on the labour market as they are facing a number of challenges in the school to work transition. At the same time, economic recession and political instability still reduce their chances to integrate into the domestic labor market. Thus, researches focusing on the transition from school to work have both highlighted a range of individual and systemic factors that influence the occupational integration of young people in Moldova (Buciuceanu-Vrabie \& Gagauz, 2017; Ganta \& Shamchiyeva, 2016): limited number of jobs and low quality jobs, low salaries, informality; continuous emigration flows, dependence on remittances; regional and rural/urban discrepancies; unequal opportunities, low mobility; gender gap in the access and quality of employment (young women, especially with little children, being most discouraged on the labour market).

The cumulative effect of all these problems is leading to "dis-integration', which means the disengagement and alienation of young population of the country from three central forms of citizenship. From political citizenship, as they feel that the government is not pursuing the right policies and the level of trust in public institutions is low. From economic citizenship, as they are unable to find jobs or to enter the formal labour market and from social citizenship, as they feel that the state is not giving them the kind of support through life transitions (Abbott, Wallace, \& Mascauteanu, 2010). As a result, many young people choose to go abroad and increasing rates of emigration during the last decades come to confirm that.

Therefore, not only the complexity of the problems is reiterated, but also the requirement for a comprehensive, cross-sectoral, coherent policy targeting different categories of young people in their transition to independent adult life.

Conceptual framework. The conceptual and analytical framework of relevant policy measures to support young people in transition to independent adult life is known as the Youth Transition Regime developed by Walther (Walther \& Pohl, 2007; Walther, 2006) and the Youth Welfare Citizenship developed by Chevalier (Chevalier, 2016; Chevalier, 2017). The 'Youth Transition Regime`

${ }^{1}$ This indicator measures the share of youth affected by multiple deficits in the areas of education, employment, health, civic participation and social inclusion at the same time, OECD, 2017. 
encompasses the institutional and policy framework, which includes education and training systems, employment regulation and social protection system (Walther, 2006). The "de-standardization` of youth transition and the emergence of new risks of social exclusion have led to the development of new transition policies ('activation ' policies, social investment policies etc.). These policies differ widely between countries, but all tend to reduce dependence on social protection towards labour market integration, while school-to-work transitions are primarily focused on 'disadvantaged young people`. Young people are disadvantaged if they do not have key premises and resources for a standard transition process and refer to an interconnected model between the structure and the agency (Walther \& Pohl, 2007) (Figure 1).

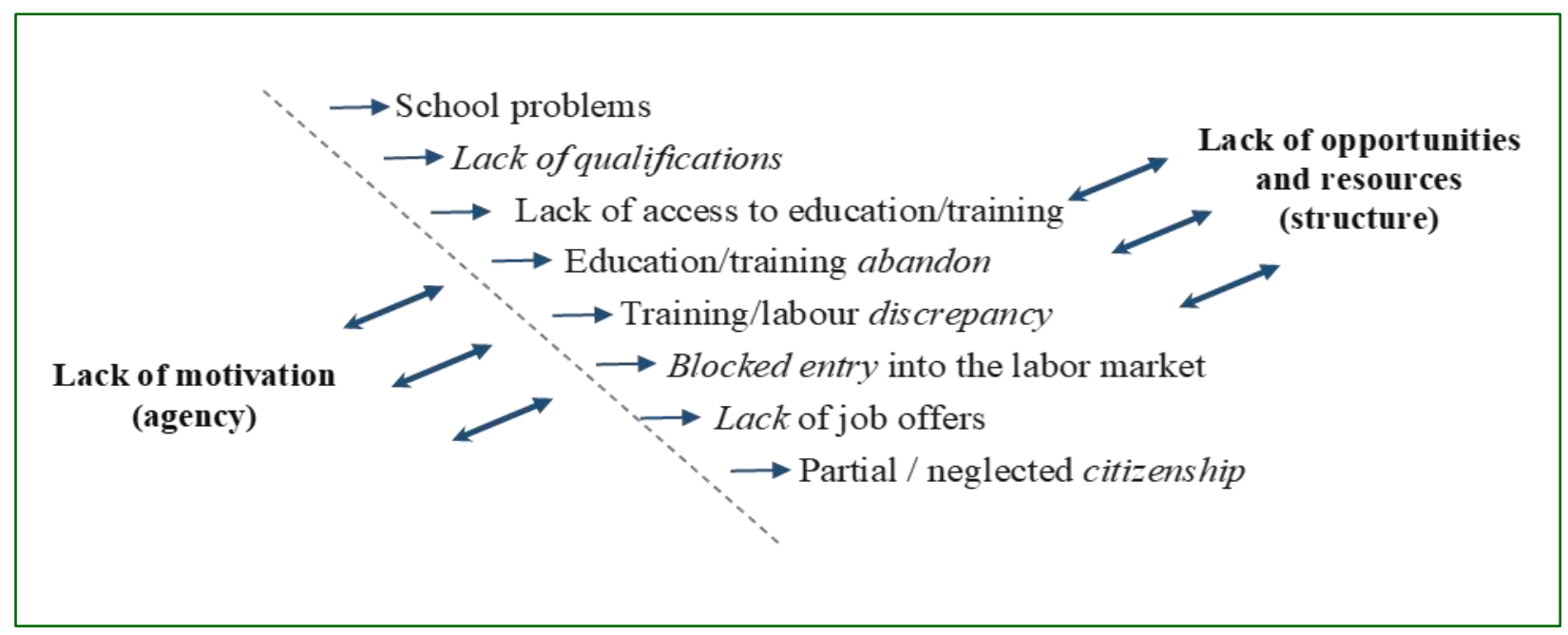

Figure 1. Interconnected model between the structure and the agency Source: Walther, 2007.

Furthermore, in relation to school-to-work transitions two main ways of interpreting (diagnosing) and approaching (policies) disadvantages are identified:

$\checkmark$ 'Young people are disadvantaged because they are unemployed' - a structural diagnosis that requires structural policies to increase labour demand. Relevant in countries where the youth unemployment rate is high.

$\checkmark$ 'Young people are unemployed because they are disadvantaged - a diagnosis that refers to individual deficiencies, i.e. lack of skills or unwillingness to work, and the need for policies aimed at helping young people by increasing their employability (training).

Another aspect in policy analysis is 'preventive vs. compensatory'. If the policy actions are preventive, then the approach is broader and mostly related to infrastructure, while the compensatory ones are focusing on young people who are already facing disadvantages, for example those who have dropped out of school or are unemployed.

Chevalier [Chevalier, 2019; Chevalier, 2016] calls policies aimed at promoting youth autonomy 'Youth Welfare Citizenship', i.e. the possibility for young people to access financial resources for maintenance and participation in society, which is structured through state interventions and public policies. The state can promote this independence by helping individuals to get a job, a process called 'economic citizenship' regulated by education and employment policies. At the same time, it can offer young people resources in the form of aid/allowances, such as support for the family, for pupils/students, for purchasing a dwelling, unemployment benefits, which is called `social citizenship`. As well, Chevalier (Chevalier, 2019) specify that economic citizenship may have two forms - inclusive' (from the 'learning-first' perspective) or `selective` (from the 'work-first' perspective). It is inclusive when it seeks to provide skills to all young people by reducing early school abandonment. Subsequently, employment policy proposes programs to provide a second chance to low-skilled young adults (i.e. in the EU there is the 'Youth Guarantee` program). On the contrary, it is selective when the education system is elitist and produces significant educational inequalities. The employment policy, from the 
perspective of 'work-first' focuses on reducing labour costs and creating atypical jobs that would make it easier for young people to access jobs. It does not have the prerogative to compensate for inequalities in education or to offer a second chance, but rather to develop low-skill jobs. The `social citizenship` is divided into 'familiarized`vs. 'individualized`. It is 'familiarized when young people are considered children, given the high age limits (approximately 25 years) and they remain 'dependent children` in social protection. In turn, is 'individualized when young people are considered adults, and lower age limits allow them to more easily access social assistance/allowances.

\section{DATA SOURCES AND USED METHODS}

In order to achieve study goals the mixed-method approach was applied: (i) situation and contextual analysis; (ii) desk review of relevant secondary data sources as international and national organization reports, governmental reports and primary data targeting young people; (iii) in-depth analysis of key youth policy documents, including cross-sectoral, analysis of existing policy evaluation reports and studies.

Existing relevant normative frameworks and policies were analyzed with a focus on: overall national normative framework and development policies that have a direct impact on youth policies. At the same time, assessment of existing Government Youth-Related Policies in response to youth needs, problems and vulnerability was implied.

\section{RESULTS OF OWN RESEARCH AND DISCUSSIONS}

National youth policy framework. A sufficient legal and conceptual strategic framework in the youth field, but also a series of important policy documents that regulate the activity and guide the country youth policies is attested. The national legal framework has been modified in accordance with new realities and trends, including at regional and global levels, and also in line with the provisions of international and regional treaties and conventions to which the Republic of Moldova is part. For the most part, the sector was strengthened with the approval of the National Strategy for Youth Sector Development (2014-2020) and Action Plan on its implementation (2014) and subsequently with the approval of the Law on Youth (2016).

This Strategy focuses mainly on expanding existing services and creating new ones in four strategic areas: youth participation; youth services; economic opportunities for young people; strengthening the youth sector. The evaluation report on the implementation of the Strategy have attested certain progresses in terms of developing structures for youth services and participation (youth centers, local youth councils, etc.), but also highlighted a range of systemic problems, such as reduced capacity at all levels concerning human and financial resources, a narrow spectrum of targeted services for different categories of young people, their concentration in the urban area, as well as a deficient mechanism of connection between the parties involved (Gagauz, Stratan, Buciuceanu-Vrabie, \& Crismaru, 2020).

The Law on Youth (No 215 from 29.07.2016) regulates the principles and goals of youth policies based on cross-sectorial cooperation. The priority areas stipulated in the Law are economic opportunities; multilateral participation and development; healthy lifestyle; services and programs for youth people. This Law introduced important changes in the youth sector, ensuring a legislative update to the needs of youth, youth workers and specialists, other interested parties. This document included several new definitions and terms, such as non-formal and informal education of young people, peer educators, etc. The category of persons falling under the scope of this Law was extended to persons between the ages of 14 and 35 (in the Law of 1999 the category ranged between persons aged 16-30). Nevertheless, about half of the 55 provisions stipulated in the Law are vague and largely descriptive, meaning a low impact on the way the authorities address the issues of young people (UNICEF, 2017).

It should be mentioned that in the main legislative and normative acts "youth 'is largely treated as a homogeneous group not distinguishing specific groups by age, gender, place of residence, ethnicity, etc. Even if young people with limited opportunities are mentioned in both the Law on Youth and the Strategy, specific groups are not delimited (e.g. young people with disabilities, ethnic minorities, unemployed, Education or Training young people, etc.).

Despite the improvement of the normative and institutional framework on youth sector, the effective implementation and enforcement of legislation remains a challenge. As a specialized central public administration body that develops and promotes youth policies nationally, the Ministry of 
Education, Culture and Research does not have subordinated regional territorial units in the field of youth and does not have efficient tools and mechanisms to influence the implementation of the legal framework locally. At the same time, responsibilities delegated to Local Public Authorities regarding the identification of financial, material and human resources for promoting youth programs in the territory cannot be fully fulfilled due to limited financial, logistical and human possibilities.

Education policy beyond the lower secondary level. During the last decade several comprehensive documents that set the policy priorities in the area of education and training were developed and approved. These are the Education Development Strategy for 2014-2020 `Education 2020' and "Strategy for the Development of Vocational Education and Training (VET) 2013-2020'. In 2014 a new Code of Education was adopted, establishing the legal framework for organizing, implementing and developing education, and provides the basis for modernizing the education and training system. The main objectives of the reference documents are to increase access to education for all children and young people, including vulnerable groups, and to provide quality education at every level, from early childhood development to higher education, ensuring that studies are relevant to the necessities of life, active citizenship and career success.

The country's educational system underwent several important changes over the past years. Thus, in response to demographic decline and low efficiency in primary and secondary education, a school network optimization has been carried out. These reforms targeted VET providers as well, but have not yet included higher education institutions. Whereas these optimization reforms have had some positive impact in urban areas, in rural areas they could not slow down the decline in key efficiency indicators (WorldBank, 2018). Moreover, despite the implementation of a costly VET reform aimed at supporting the socioeconomic development of the country, it has not fully reached its goals. The accessibility of higher education for a wider segment of young people has made vocational education less attractive with a decrease in the number of students in the VET system.

Therefore, the policy of education has been focused on reforms and was oriented towards expanding access to education, connecting to the new requirements and challenges. However, the main problems in this sector continue to persist: high rate of early leavers from education, high NEET rate, low quality and mismatch between education and labour market requirements and other issues. Thus, the rate of early leavers from education and training is actually quite high, the percentage of people aged 18 to 24 with at most lower secondary education and not in further education or training was around 21\% in 2018 (NBS, 2019). This indicator is twice the EU average - 10.6\% (Eurostat, 2019). Furthermore, in 2018 almost $24 \%$ or every fourth person aged 15-29 had NEET status. The rate is especially high among women compared to men $(30,2 \%$ vs. $18,1 \%)$, which has validity for both urban and rural areas (NBS, 2019).

Policy measures. Analysing the policy measures in terms of youth transition dimensions, it may be concluded that policy measures are 'inclusive' given that they try to provide skills and competencies to as many young people as possible, and then through training/vocational programs to give a second chance to low-skilled young people. At the same time, measures to reduce early school leaving are 'compensatory' and not 'preventive' since they are aimed at young people who have already left the education system. There is no clear and functional mechanism for monitoring this phenomenon, there are no specific measures for prevention and intervention, and there is no cross-sectoral cooperation in combating this phenomenon.

Labour market policy for youth. One of the priority areas for intervention and development stipulated in the Law on Youth (2016) is 'economic opportunities for young people`. In the National Strategy for the Development of the Youth Sector (2014-2020) among the main objectives there are economic empowerment and entrepreneurship of young people for increasing employment opportunities. According to the Law on the Promotion of Employment and Unemployment Insurance young people aged between 16 and 24 are defined as a group that needs additional support on the labour market. In the National Employment Strategy (2017-2021) special attention is paid to employment policies of the young population for their integration and maintaining on the labour market. The emphasis is on increasing the social inclusion of all young people, facilitating the transition from school to work, focusing in particular on integration into the labour market. 
Moreover, the National Employment Agency implements a range of active measures to stimulate employment, including counseling, guidance and vocational training. Although it does not promote specific measures for young people, according to activity reports, about $30 \%$ of the beneficiaries of these measures are people aged 16-29 (NEA, 2019).

Therefore, in the strategic reference documents, youth employment is included in the policymaking process as a cross-cutting issue of major importance. Nevertheless, the reports evaluations based on key labour market indicators confirm that country still faces serious structural problems, such as informal work, low labour market participation, insufficient and inadequate quality jobs, inequalities and skill mismatches (Buciuceanu-Vrabie \& Gagauz, 2017), (Crismaru, Gagauz, \& Buciuceanu-Vrabie, 2018). According to official statistics, in 2018 the employment rate among young people aged 15-24 years was 20,9\%, which is the lowest compared to other age categories and it increases with the age (NBS, 2019). Thus, among people aged 25-34 the employment rate constitutes 50,3\%, i.e. every second persons of this age is participating on the labour market. The employment rate varies significantly by area of residence and gender for both age categories. The rates are higher in urban areas and among young men.

Policy measures. Analyzing in terms of terms of youth transition dimensions, employment policy measures for young people are largely `individualized as young people are seen as a disadvantaged group on the labor market. Thus, the actions are largely oriented towards increasing the employability of young people through counseling, professional training, etc. These are mostly `compensatory and not 'preventive` since they are oriented to young people already facing disadvantages. However, policy measures need to be more focused on promoting the growth of quality youth jobs. Macroeconomic and sectoral measures with provisions to improve employment and productivity, to promote entrepreneurship among young people are imperative in the case of Moldova.

Social welfare policy. In the Republic of Moldova these policies focus mainly on measures related to the social protection of families with small children and maintaining the jobs of mothers by granting a childcare leave of up to 4 years. The financial support of families with children provided by the state is applied in the form of allowances paid periodically or monthly upon childbirth and during childcare depending on the family's status on the labour market, income level and age of the child.

It can be concluded that these policies are mostly 'family-centered' with a number of benefits for families with small children. After the latest amendments to the legislation, mothers have paid childcare leave up to 2,2/3 years and unpaid childcare leave up to 4 years. At the same time there is no multisectoral vision of providing benefits for each child up to 18 years as in most developed countries. Existing policies are mainly focused on categories of beneficiaries than on a targeted approach per child and the measures applied are carried out more post-factum to confirm poverty than to prevent it based on risk (Expert-Grup, 2014).

In the context of the Youth Transition Regime the access of young people to housing is a topic of major importance both in terms of policies developed by the state to support young people and in terms of policy modelling to reduce youth migration. According to the Law on Youth (2016), the State adopts specific measures to provide young people with housing by supporting the construction of houses for young people and young families and develop policies on purchasing dwelling by young people and young families.

In order to increase access to housing the "Prima Casă" (eng. 'First House') State Program (2017) was launched, designed to facilitate the access of individuals to purchase a home by contracting mortgages partially guaranteed by the state. A major objective of this program is to discourage the emigration of young specialists abroad. Although it was originally planned for young people up to 35 years old, it was later extended to people aged 18-45. The data show that since the launch of the "Prima Casă" (eng. 'First House') State Program so far 4031 applications have been registered, of which 3871 have been accepted (96\%). Thus, according data available website, out of the 3871 beneficiaries, 2720 are families and 1151 are unmarried young people, the average age of the applicants being 31.3 years. Despite the efforts made by public authorities to increase access to housing for young people through the "Prima Casă" (eng. 'First House') State Program and other support programs, the number of young people benefiting from these programs is low, while the migration rate among them continues to increase. 


\section{CONCLUSIONS}

In recent decades the legal and conceptual framework that defines and guides youth policies in the Republic of Moldova has changed considerably, in line with new realities and challenges. Despite the improvement of the regulatory framework, the implementation and effective enforcement of legislation remains a challenge, mainly due to limited financial, logistical and human possibilities of central and local public authorities.

The review and analysis of the policy framework has revealed that youth issues are promoted by various policies and some are part of national sectorial strategies. However, a lack of an integrated approach and a comprehensive evaluation mechanism on the implementation of youth policies is attested, including on a cross-sectoral dimension. Regardless of the intersectoral character of youth issues recognition and its stipulation in policy documents, the collaboration between different state institutions in the field of youth is insufficient and often purely formal.

Despite relatively large public investments in education system, as well as the implementation of important reforms and programs, educational and training institutions fail to cope with issues such as the mismatch between education and training outcomes and labour market requirements, high rate of early leavers from education and training, high NEET rate, etc. Subsequent actions aimed at increasing the employability of young people are not able to make up for the shortcomings in the early stages of human capital formation and the lack of adequate social investment in this area.

It can be stated that the Youth Transition Regime in Moldova falls under the 'transitional' category according to the classification developed by Pohl and Walther. It is characterized by an integrated education system, the predominance of general education; high rate of early school leavers; low popularity/prominence of VET; poor quality of education. At the same time, active employment measures are relatively underdeveloped; there is evidence of a focus on developing employment skills; high incidence of temporary/low quality jobs; mismatch of competencies.

The assessment of policy measures designed to facilitate the transition of young people to adulthood shows that individualized and compensatory approaches predominate. Policy actions are mainly focused on youth skills development and addressing individual deficiencies and less on structural policy measures in cross-sectoral areas. Although, in case of early education and training abandonment training, preventive measures are indicated. At the same time, it involves increased risks at the individual level and exerts more pressure on the family. Some of the provisions of policies aimed at promoting the autonomy of young people in terms of 'Youth Welfare Citizenship' are declarative in nature and hardly implemented.

Social policies are mostly family-centered, with a number of benefits for families with small children, albeit insufficient. The state's policy of increasing access to housing is at an early stage and still poorly developed, so it does not play a significant role in relation to the situation of young people in the country's housing market.

There is a need to review and adapt youth policies and strategies to the current and real needs of this population category. At the same time, given the strong segmentation of the young population from a socio-demographic, economic and aspirational point of view, specific, nuanced and adequately targeted institutional responses are needed.

Participatory development of the new youth development strategies by reflecting the diversity of youth in Moldova, the interests and needs of youth from various social groups, especially from the socially vulnerable ones must be promoted. This process should involve more discussions in focus groups with identified categories of youth who are facing specific vulnerabilities/needs and have limited opportunities to identify the desired support and activities that would be included in the strategy and plan in order to solicit their ideas for goals and actions.

\section{REFERENCES}

1. ABBOTT, P., WALLACE, C., MASCAUTEANU, M. Concepts of citizenship, social and system integration among young people in post-Soviet Moldova. In: Journal of Youth Studies. 2010, vol. 13, no. 5, pp. 581596. ISSN 1367-6261.

2. BUCIUCEANU-VRABIE, M., GAGAUZ, O. Youth on the labour market in the Republic of Moldova: competences and aspirations. Chisinau, 2017. 
3. CHEVALIER, T. Varieties of youth welfare citizenship: Towards two-dimensional typology. In: Journal of European Social Policy. 2016, no 26 (1), pp. 3-19. ISSN 0958-9287.

4. CHEVALIER, T. Social citizenship of young people in Europe: A comparative institutional analysis. In: Journal of Comparative Policy Analysis: Research and Practice. 2018, vol 20, issue 3, pp. 304-323. ISSN 1387-6988.

5. CHEVALIER, T. Political trust, young people and institutions in Europe. A multilevel analysis. In: International Journal of Social Welfare. 2019, vol. 28, pp. 418-430. ISSN 1468-2397.

6. CRISMARU, M., GAGAUZ, O., BUCIUCEANU-VRABIE, M. Inclusion of youth not in Employment, Education or Training (NEET youth). Chișinău, 2018.

7. DENSTAD, F. Youth Policy Manual. How to develop a national youth strategy. Council of Europe Publishing. 2009. 92 p. ISBN 978-92-871-6576-3.

8. EUROSTAT. 2019 [cited 24 october 2020]. Available: https://ec.europa.eu/eurostat/data/database.

9. EXPERT-GRUP. Politici de susținere a familiilor cu copii: viziune de politici în Uniunea Europeană şi propuneri pentru Republica Moldova. 2014, 14 iulie [cited 24 october 2020]. Available: https://expertgrup.org/en/biblioteca/item/987-unicef-1

10. GAGAUZ, O., STRATAN, A., BUCIUCEANU-VRABIE, M., CRISMARU, M. Analiza Comprehensivă a Sectorului de Tineret. Chișinău, 2020

11. GANTA, V., SHAMCHIYEVA, L. Tranziția tinerelor și tinerilor spre piața muncii în Republica Moldova. Rezultatele analizei din 2013 și 2015 privind tranziția de la școală la muncă. Seria de publicații Work4Youth, nr. 38. Organizația Internațională a Muncii. Geneva: Biroul Internațional al Muncii, 2016. 68 p. ISSN 2309-6780.

12. LECCARDI, C. Redefining the Future: Youthful. New directions for child and adolescent developpment. 2006. DOI:10.1002/cad.167

13. Lege cu privire la tineret: nr. 215 din 29.07.2016. In: Monitorul Oficial al Republicii Moldova. 2016, nr. 315-328, art. 688 [cited 24 october 2020]. Available:

https://www.legis.md/cautare/getResults?doc_id=105800\&lang=ro

14. NATIONAL BUREAU OF STATISTICS. 2019 [cited 17 october 2020]. Available: https://statistica.gov.md/

15. NATIONAL EMPLOYMEN AGENCY. 2019 [cited 22 october 2020]. Available: https://www.anofm.md/

16. OECD. Youth Well-being Policy Review of Moldova: EU-OECD Youth Inclusion Project, Paris, 2018. 100 p. [cited 20 october 2020]. Available: https://www.oecd.org/countries/moldova/Youth_Wellbeing_Policy_Review_Moldova.pdf

17. PÎSLARU, N. et. al. Pilonul european al drepturilor sociale: reducerea inegalităților și a decalajelor sociale în România. Evoluții ale politicilor și inițiativelor europene din domeniul tineretului. Bucuresti, 2019. 213 p. [cited 14 october 2020]. Available: http://ier.gov.ro/wp-content/uploads/2019/03/FINAL_Studiul4_Spos-2018.pdf

18. TAYLOR-GOOBY, P. New Risks and Social Change. New York: Oxford University Press, 2005. DOI:10.1093/019926726X.003.0001

19. UNICEF. Capacity gap analysis of local public authorities and of local youth councils to promote and implement youth policy at local lev. Chisinau, 2017.

20. WALTHER, A. Regimes of youth transition: Choice, flexibility and security of young people's experiences across different European contexts. In: Nordic Journal of Youth Research, 2006, vol. 14, issue 2, pp. 119139. DOI: $10.1177 / 1103308806062737$

21. WALTHER, A., \& POHL, A. Activating the disadvantaged. Variations in addressing youth transitions across Europe. In: International Journal of Lifelong Education, 2007, vol. 26, issue 5, pp. 533-553. DOI:10.1080/02601370701559631

22. WORLDBANK. Moldova: Education Sector Public Expenditure Review Selected Issues. Washington: World Bank, 2018. 53 p. [cited 14 october 2020]. Available: https://openknowledge.worldbank.org/bitstream/handle/10986/29729/125331-WP-P161676-MDMini-PER-final-for-imagebank4-2018.pdf?sequence=1\&isAllowed=y

\section{ARTICLE HISTORY}

Received 02 June 2020

Accepted 01 December 2020 